\title{
Chemical constituents of Euphorbia tirucalli L.
}

\author{
Le Thi Kim Dung, Bui Xuan Hao, Nguyen Thi Anh Tuyet, Pham Nguyen Kim Tuyen, \\ Duong Thuc Huy*
}

\begin{abstract}
Euphorbia tirucalli has not been chemically studied much in Vietnam. This research described the isolation and elucidation of compounds isolated from the plant collected in Binh Thuan. Multiple chromatographic methods were applied, including normal phase silica gel column chromatography and thin-layer chromatography. Seven compounds were isolated and their chemical structures were elucidated by spectroscopic analysis as well as comparing their data with the ones in the literature. They are arjunolic acid (1), eriodictyol (2), quercitrin (3), afzelin (4), scopoletin (5), 3,3',4trimethylellagic acid (6), and gallic acid (7). Among them, compound 1 a major component was isolated for the first time in Euphorbia genus, while three compounds 2,4 , and 5 were isolated from this species for the first time.
\end{abstract}

Keywords - arjunolic acid, phenolic compounds, flavonoid, Euphorbia tirucalli

\section{INTRODUCTION}

E uphorbia tirucalli L. belons the Euphorbiaceae family and is a popular herb in traditional herbal medic ne (10). There are approximately 1600 species in the Euphorbia genus. Some species of thi $B$ pus have long been used as herbal drug in Chma, India, Brazil and Southeast Asia. Euphorbia tirucalli L. is traditionally used in Vietnam. The extract and pure compounds from Euphorbia tirucalli were evaluated some biological activity, including antioxidant and antimicrobial [3], antifungal, antiviral [4], anti-inflammatory [5], cytotoxicity [6], and enzyme inhibitory activities [7].

Previous phytochemical investigation on the plant Euphorbia tirucalli reported the presence of phytosterols, tritepenes, diterpenes, polyphenols,

Received 29-05-2017; Accepted 12-10-2018; Published 2011-2018

Le Thi Kim Dung ${ }^{1}$, Bui Xuan Hao ${ }^{1}$, Nguyen Thi Anh Tuyet $^{1}$, Pham Nguyen Kim Tuyen ${ }^{2}$, Duong Thuc Huy ${ }^{1 *}$ ${ }^{1}$ University of Pedagogy - Ho Chi Minh City, Vietnam; ${ }^{2}$ Saigon University - Ho Chi Minh City, Vietnam

*Email: huydt@hcmue.edu.vn tannins, .... [2, 8-10]. The latex from Euphorbia tirucalli showed the presence of ingenane- and tigliane-diterpenoids [2, 11, 12]. Up to 2017, no chemical studies on Euphorbia tirucalli were reported in Vietnam. Herein the isolation and structure elucidation of seven compounds (1-7) were presented (Fig. 1).

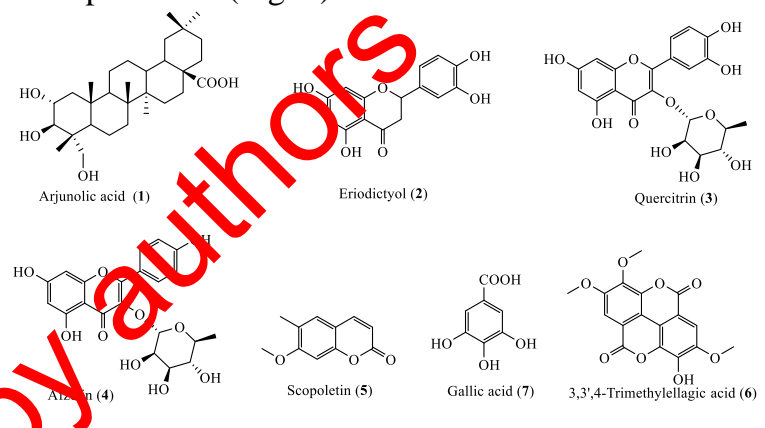

Fig.1. Chemical structures of 1-7

\section{MATERIALS AND METHODS}

\section{General experimental procedures}

NMR spectra were measured on Bruker Avance III $\left(500 \mathrm{MHz}\right.$ for ${ }^{1} \mathrm{H}$ NMR and $125 \mathrm{MHz}$ for ${ }^{13} \mathrm{C}$ NMR) spectrometer. Proton chemical shifts were referenced to the solvent residual signal of $\mathrm{CD}_{3} \mathrm{COCD}_{3}$ at $\delta_{\mathrm{H}} 2.05$. The ${ }^{13} \mathrm{C} \mathrm{NMR}$ spectra were referenced to the central peak of $\mathrm{CD}_{3} \mathrm{COCD}_{3}$ at $\delta_{\mathrm{C}}$ 29.4. HR-ESI-MS were recorded on a Bruker microTOF Q-II. TLC analyses were carried out on pre-coated silica gel $60 \mathrm{~F}_{254}$ or silica gel $60 \mathrm{RP}-18 \mathrm{~F}_{254} \mathrm{~S}$ (Merck) and spots were visualized by spraying with $10 \%$ $\mathrm{H}_{2} \mathrm{SO}_{4}$ solution followed by heating. Column chromatography (CC) was performed using silica gel 60 (0.040-0.063 mm, Himedia).

\section{Plant material}

The whole fresh plant of Euphorbia tirucalli (Euphorbiaceae) was collected from Hong Son village, Ham Thuan Bac, in Binh Thuan province in July 2014. The botanical sample was authenticated by Dr. Pham Van Ngot, 
Department of Botany, Faculty of Biology, Ho Chi Minh University of Pedagogy, Vietnam.

\section{Extraction and isolation}

The dried sample was milled to obtain $3.5 \mathrm{~kg}$ of powder. The powder was extracted with EtOH $(2 \mathrm{x}$ $10 \mathrm{~L}$ ) at $70{ }^{\circ} \mathrm{C}$, to obtain the EtOH-soluble extract. While this solution was being evaporated, a precipitant (P, $250.4 \mathrm{~g})$ occurred and was filtered off. The remaining solution was evaporated until dryness to obtain crude ethanolic extract ( $290.3 \mathrm{~g}$ ).

The resultant ethanolic extract was sequentially partitioned with $n$-hexane, EtOAc, and $n$-BuOH to afford the extracts $\mathbf{H}(94.2 \mathrm{~g}), \mathbf{E A}(61.8 \mathrm{~g})$, and Bu $(27.0 \mathrm{~g})$, respectively. The EA extract was applied to a silica gel CC and eluted with a solvent system of $n$-hexane:EtOAc with the ratio 8:2, 5:5, and 0:10, to afford 3 fractions, EA1 (10.32 g), EA2 $(2.5 \mathrm{~g})$, and EA3 (2.19 g), respectively. The fraction EA2 was fractionated by $\mathrm{CC}$ with the solvent system $n$-hexane:EtOAc (1:4), to afford three fractions EA2.1-3. Fraction EA2.1.3 (548.0 $\mathrm{mg}$ ) was further applied to a silica gel CC eluted with $n$-hexane:EtOAc:EtOH:AcOH $\quad$ (5:1:0.2:0.1) to afford three sub-fractions EA2.1.3.1-3. Subfraction $\quad$ EA2.1.3.1 $\quad(150.1 \quad \mathrm{mg})$ rechromatographed to obtain two compound $(4.3 \mathrm{mg})$ and $7(20 \mathrm{mg})$. Sub-fraction F, 2.113.2 (356 mg) was purified by preparative $\mathrm{LC}$ using chloroform: $\mathrm{MeOH}: \mathrm{H}_{2} \mathrm{O} \quad(4: 0.38: 0.02)$ to obtain three compounds $2(6.5 \mathrm{mg}), 3(10.0 \mathrm{mg})$, and 4 (4.3 mg).

The precipitant $\mathbf{P}$ (250.4 gyas dissolved in hot solution of acetone: $\mathrm{FOH}(1)$ then sequentially partitioned with $n$-hexa e, EtOAc, and $n$-BuOH, to afford the extracts PH (100.4 g), PA (64.0 g), PB $(21.0 \mathrm{~g})$, respectively. The extract PA was applied to asilica gel $\mathrm{CC}$, and eluted with a solvent system of $n$-hexane:EtOAc (8:2, 5:5, and 0:10), to afford 3 fractions, PA1 (11.26 g), PA2 (8.42 g), and PA3 (17.14 g), respectively. A part of fraction PA1 (1.0 g) was concentrated to dryness and washed three times by acetone, to obtain compound $\mathbf{6}$ (120.0 $\mathrm{mg}$ ). A part of fraction PA2 (150.0 mg) was carried out in the same manner as fraction PA1 to obtain compound 2 (10.3 mg).

Arjunolic acid (1). White amorphous powder; the ${ }^{1} \mathrm{H}$ and ${ }^{13} \mathrm{C}$ NMR (acetone- $d_{6}$ ) spectroscopic data, see Table 1 .
Eriodictyol (2). White amorphous powder; the ${ }^{1} \mathrm{H}$ and ${ }^{13} \mathrm{C}$ NMR (acetone- $d_{6}$ ) spectroscopic data, see Table 2 .

Quercitrin (3). Light-yellow amorphous powder; the ${ }^{1} \mathrm{H}$ and ${ }^{13} \mathrm{C}$ NMR (acetone- $d_{6}$ ) spectroscopic data, see Table 2.

Afzelin (4). Light-yellow amorphous powder; the ${ }^{1} \mathrm{H}$ and ${ }^{13} \mathrm{C}$ NMR (acetone- $d_{6}$ ) spectroscopic data, see Table 2.

Scopoletin (5). Light-yellow amorphous powder; ${ }^{1} \mathrm{H}$ NMR (acetone- $\left.d_{6}\right), \quad \delta$ : $3.90 \quad$ (6$\left.\mathrm{OCH}_{3}\right), 6.17$ (d, $\left.J=9.5 \mathrm{~Hz}, \mathrm{H}-3\right), 6.80(s, \mathrm{H}-8)$, $7.19(s, \mathrm{H}-5), 7.84(d, J=9.5 \mathrm{~Hz}, \mathrm{H}-4) .{ }^{13} \mathrm{C}$ NMR (acetone- $\left.d_{6}\right), \delta$ : 160.4 (C-2), 112.4 (C-3), 143.7 (C-4), 109.1 (C-5), 14.9(C-6), 154.1 (C-7), 102.8 (C-8), 150.9 (C 9), 111.2 (C-10), 55.7 (6$\left.\mathrm{OCH}_{3}\right)$.

3,3',4-Trim ty acid (6). White amorphous 1 ouder; the ${ }^{1} \mathrm{H}$ and ${ }^{13} \mathrm{C}$ NMR (acetone-d6) pectroscopic data was suitable to those in riterature [9].

Galli acid (7). White amorphous powder; the 1. ${ }^{13}{ }^{13} \mathrm{C}$ NMR (acetone- $d_{6}$ ) spectroscopic data Mas suitable to those in the literature [8].

\section{RESULTS AND DISCUSSION}

Three successive extractions were performed on the crude ethanol extract of the whole plant Euphorbia tirucalli. Further purification and isolation of compounds were carried out using silica gel chromatography, as described in the experimental section. Seven compounds were isolated and their structures were elucidated as arjunolic acid (1), eriodictyol (2), quercitrin (3), afzelin (4), scopoletin (5), 3,3',4-trimethylellagic acid (6), and gallic acid (7).

Compound $\mathbf{1}$ was obtained as a white amorphous powder. The ${ }^{1} \mathrm{H}$ NMR and HSQC spectra of 1 showed the presence of six quaternary methyls at $\delta_{\mathrm{H}} 0.73(3 \mathrm{H}, \mathrm{s}), 0.80(3 \mathrm{H}$, s), $0.92(3 \mathrm{H}, \mathrm{s}), 0.94(3 \mathrm{H}, \mathrm{s}), 1.02(3 \mathrm{H}, \mathrm{s}), 1.17$ $(3 \mathrm{H}, \mathrm{s})$, two oxymethine protons at $\delta_{\mathrm{H}} 3.39(1 \mathrm{H}$, $\mathrm{d}, J=9.5 \mathrm{~Hz})$ and $3.67(1 \mathrm{H}$, ddd, $J=11.5,9.5$, $4.5 \mathrm{~Hz})$, one oxymethylene group at $\delta_{\mathrm{H}} 3.28(1 \mathrm{H}$, $\mathrm{d}, J=10.5 \mathrm{~Hz})$ and $3.56(1 \mathrm{H}, \mathrm{d}, J=10.5 \mathrm{~Hz})$, and one olefinic proton at $\delta_{\mathrm{H}} 5.25(1 \mathrm{H}, \mathrm{dd}, J=$ 7.0, $3.5 \mathrm{~Hz})$. The ${ }^{13} \mathrm{C}$ NMR spectrum, in accordance with HSQC spectrum, confirmed the presence of thirty carbons comprising two olefinic carbons ( $\delta_{\mathrm{C}} 122.9$ and 145.0), one hydroxycarbonyl carbon $\left(\delta_{\mathrm{C}}\right.$ 178.9$)$, two 
oxymethines ( $\delta_{\mathrm{C}} 68.9$ and 78.5$)$, one oxymethylene $\left(\delta_{\mathrm{C}} 67.1\right)$, and six methyls $\left(\delta_{\mathrm{C}} 13.8,17.5,17.7\right.$, 23.7, 26.4, 33.4). the comparison of the ${ }^{13} \mathrm{C} \mathrm{NMR}$ data of 1 and those of oleanolic acid [14] indicated the same structures of B, C, D, and E rings of $\mathbf{1}$ and those of oleanolic acid, except for the ${ }^{13} \mathrm{C}$ NMR signals in the A-ring. This finding led to the identification of the position of the oxygenated methine and methylene groups in the A-ring. In HMBC spectrum, proton $\mathrm{H}-3\left(\delta_{\mathrm{H}} 3.39, \mathrm{~d}, 9.5 \mathrm{~Hz}\right)$ showed cross-peaks to signals at $\delta_{\mathrm{C}} 47.4$ (C-1), 68.9 (C-2), 43.4 (C-4), 13.8 (C-24) and proton $\mathrm{H}-2$ $\left(\delta_{\mathrm{H}} 3.67\right.$, ddd, $\left.11.5,9.5,4.5 \mathrm{~Hz}\right)$ correlated to $\mathrm{C}-1$, $\mathrm{C}-4$, and $\mathrm{C}-3\left(\delta_{\mathrm{C}} 78.5\right)$, which indicated their vicinal positions (Fig. 2). Moreover, the coupling constant $(J=9.5 \mathrm{~Hz})$ between protons $\mathrm{H}-3$ and H-2 indicated their axial positions [24]. On the other hand, while axial proton $\mathrm{H}-3$ was at the $\beta$ orientation, found in many oleanane tritepenens [14], proton $\mathrm{H}-2$ was defined at the $\alpha$ one. The oxymethylene protons at $\delta_{\mathrm{H}} 3.28(\mathrm{H}-23 \mathrm{a}, \mathrm{d}, J=$ $10.5 \mathrm{~Hz})$, and $3.56(\mathrm{H}-23 \mathrm{~b}, \mathrm{~d}, J=10.5 \mathrm{~Hz})$ showed HMBC correlations to C-3, C-4, and C24 , to determine their positions. The comparison of NMR data of $\mathbf{1}$ and those of arjunolic acid $[15,16]$ showed that they were identical, accordingly, 1 was elucidated as arjunolic acid (Table 1). Arjunolic acid was found in Terminalia arjuna tree and other plants [17] and isolated as a major component from the apolar fraction H2.4 of Euphorbia tirucalli.

Table 1. NMR spectral data of compounds $\mathbf{1}$ and arjunolic a

\begin{tabular}{|c|c|c|c|c|c|c|c|}
\hline & & $1^{\mathrm{a}}$ & $\begin{array}{c}\text { Arjunolic } \\
\text { acid }^{\mathrm{b}}\end{array}$ & & & & $\begin{array}{c}\text { Arjunolic } \\
\text { acid }^{\mathrm{b}}\end{array}$ \\
\hline $\mathrm{N}$ & $\delta_{\mathrm{C}}$ & $\delta_{\mathrm{H}}, \mathrm{m} \mathrm{J}(\mathrm{Hz})$ & $\delta_{\mathrm{C}}$ & $\mathrm{N}$ & $\delta_{\mathrm{C}}$ & $\overline{\delta_{\mathrm{H}}, \mathrm{m} \mathrm{J}(\mathrm{Hz})}$ & $\delta_{\mathrm{C}}$ \\
\hline 1 & 47.4 & & 47.1 & 16 & 23.9 & & 23.9 \\
\hline 2 & 68.9 & $3.67(\mathrm{ddd}, 11.5,9.5,4.5)$ & 68.9 & 17 & 469 & & 47.0 \\
\hline 3 & 78.5 & $3.39(\mathrm{~d}, 9.5)$ & 78.7 & 18 & 42.7. & & 43.5 \\
\hline 4 & 43.4 & & 43.5 & 19 & 46.2 & & 46.3 \\
\hline 5 & 48.2 & & 48.4 & 20 & 31.3 & & 30.7 \\
\hline 6 & 18.7 & & 18.6 & $\sqrt{-1}$ & 34.5 & & 34.2 \\
\hline 7 & 33.1 & & 33.1 & 2 & 33.4 & & 33.0 \\
\hline 8 & 40.2 & & 40.1 & 23 & 67.1 & $\begin{array}{l}3.56(\mathrm{~d}, 10.5) \\
3.28(\mathrm{~d}, 10.5)\end{array}$ & 67.2 \\
\hline 9 & 48.5 & & $\sqrt{5}$ & 24 & 13.8 & $0.73(\mathrm{~s})$ & 14.0 \\
\hline 10 & 38.7 & & 0.5 & 25 & 17.5 & $1.02(\mathrm{~s})$ & 17.6 \\
\hline 11 & 24.2 & & 3.8 & 26 & 17.7 & $0.80(\mathrm{~s})$ & 17.2 \\
\hline 12 & 122.9 & $5.25(\mathrm{dd}, 7.0$, & 122.5 & 27 & 26.4 & $1.17(\mathrm{~s})$ & 26.1 \\
\hline 13 & 145.0 & & 144.1 & 28 & 178.9 & & 178.6 \\
\hline 14 & 42.6 & & 42.4 & 29 & 33.4 & $0.92(\mathrm{~s})$ & 32.9 \\
\hline 15 & 28.4 & & 28.3 & 30 & 23.7 & $0.94(\mathrm{~s})$ & 23.7 \\
\hline \multicolumn{8}{|c|}{${ }^{a}$ recorded in acetone $-d_{6},{ }^{b}$ p $p$ isine $-d_{5}$} \\
\hline & & $1^{\mathrm{a}}$ & $\begin{array}{c}\text { Arjunolic } \\
\text { acid }^{\text {b }}\end{array}$ & & \multicolumn{2}{|c|}{$1^{\mathrm{a}}$} & $\begin{array}{c}\text { Arjunolic } \\
\text { acid }^{\text {b }}\end{array}$ \\
\hline $\mathrm{N}$ & $\delta_{\mathrm{C}}$ & $\delta_{\mathrm{H}}, \mathrm{m} \mathrm{J}(\mathrm{Hz})$ & $\delta_{\mathrm{C}}$ & $\mathrm{N}$ & $\delta_{\mathrm{C}}$ & $\delta_{\mathrm{H}}, \mathrm{m} \mathrm{J}(\mathrm{Hz})$ & $\delta_{\mathrm{C}}$ \\
\hline 1 & 47.4 & & 47.1 & 16 & 23.9 & & 23.9 \\
\hline 2 & 68.9 & $3.67(\mathrm{ddd}, 11.5,9.5,4.5)$ & 68.9 & 17 & 46.9 & & 47.0 \\
\hline 3 & 78.5 & $3.39(\mathrm{~d}, 9.5)$ & 78.7 & 18 & 42.2 & & 43.5 \\
\hline 4 & 43.4 & & 43.5 & 19 & 46.8 & & 46.3 \\
\hline 5 & 48.2 & & 48.4 & 20 & 31.3 & & 30.7 \\
\hline 6 & 18.7 & & 18.6 & 21 & 34.5 & & 34.2 \\
\hline 7 & 33.1 & & 33.1 & 22 & 33.4 & & 33.0 \\
\hline 8 & 40.2 & & 40.1 & 23 & 67.1 & $\begin{array}{l}3.56(\mathrm{~d}, 10.5) \\
3.28(\mathrm{~d}, 10.5) \\
\end{array}$ & 67.2 \\
\hline 9 & 48.5 & & 48.5 & 24 & 13.8 & $0.73(\mathrm{~s})$ & 14.0 \\
\hline 10 & 38.7 & & 38.5 & 25 & 17.5 & $1.02(\mathrm{~s})$ & 17.6 \\
\hline 11 & 24.2 & & 23.8 & 26 & 17.7 & $0.80(\mathrm{~s})$ & 17.2 \\
\hline 12 & 122.9 & $5.25(\mathrm{dd}, 7.0,3.5)$ & 122.5 & 27 & 26.4 & $1.17(\mathrm{~s})$ & 26.1 \\
\hline 13 & 145.0 & & 144.1 & 28 & 178.9 & & 178.6 \\
\hline 14 & 42.6 & & 42.4 & 29 & 33.4 & $0.92(\mathrm{~s})$ & 32.9 \\
\hline 15 & 28.4 & & 28.3 & 30 & 23.7 & $0.94(\mathrm{~s})$ & 23.7 \\
\hline
\end{tabular}


Nevertheless, it has not yet been found in the Euphorbia genus. Arjunolic acid possessed various biological activities such as antidiabetic, antifungal, antibacterial, anticholinesterase, antitumor, antiasthmatic, wound healing and insect growth inhibitory activity and its potential use was taken into account as a novel promising therapeutic strategy $[17,18]$.

Compound $\mathbf{2}$ was obtained as a white amorphous powder. The ${ }^{1} \mathrm{H}$ NMR data of $\mathbf{2}$ showed the presence of two meta coupled aromatic protons at $\delta_{\mathrm{H}} 5.96$ and $5.94($ each $1 \mathrm{H}, \mathrm{d}$, $J=2.0 \mathrm{~Hz}$ ), three aromatic protons of a $1,2,4$ trisubstitutedbenzene moiety at $\delta_{\mathrm{H}} 7.03(1 \mathrm{H}, \mathrm{d}, J$ $=1.5), 6.87(1 \mathrm{H}, \mathrm{dd}, J=8.5,1.5 \mathrm{~Hz})$, and 6.86 $(1 \mathrm{H}, \mathrm{d}, J=8.5 \mathrm{~Hz})$, one methylene group at $\delta_{\mathrm{H}}$ $3.14(1 \mathrm{H}, \mathrm{dd}, J=17.0,12.5, \mathrm{~Hz})$ and $2.72(1 \mathrm{H}$, $\mathrm{dd}, J=17.0,3.0, \mathrm{~Hz})$, one oxymethine moiety at $\delta_{\mathrm{H}} 5.40(1 \mathrm{H}, \mathrm{dd}, J=12.5,3.0, \mathrm{~Hz})$, and one chelated hydroxy group at $\delta_{\mathrm{H}} 12.17$ (Table 2). The ${ }^{13} \mathrm{C}$ NMR spectrum in accordance with HSQC spectrum showed fifteen carbons comprising five aromatic methine carbons, one oxymethine at $\delta_{\mathrm{C}}$ 80.0, one methylene $\delta_{\mathrm{C}} 43.6$, one carbonyl $\delta_{\mathrm{C}}$ 197.3 and seven aromatic quaternary carb ns (including five oxygenated ones). These fi (1/4) gs led to the identification of the flavanone ketron of 2. In the A-ring, proton H-6 ( $\delta_{\mathrm{H}} 5.4$ ) nd H-8 $\left(\delta_{\mathrm{H}} 5.96\right)$ showed HMBC correlation signals at $\delta_{\mathrm{C}} 167.4(\mathrm{C}-7)$ and $\delta_{\mathrm{C}} 103.2 \mathrm{C}$ ), confirming their positions. In the B-r 119, Motons $\mathrm{H}-2^{\prime}\left(\delta_{\mathrm{H}}\right.$ 7.03), H-5' ( $\left.\delta_{\mathrm{H}} 6.87\right)$ ane $\mathrm{H}\left(\delta_{\mathrm{H}} 6.86\right)$ showed HMBC cross-peaks to ignals at $\delta_{\mathrm{C}} 146.1$ (C-3') and 146.5 (C-4'), determining the two oxygenated carbons C-3' and C-4' (Fig. 3). Moreover, the HMBC correlation betweem proton $\mathrm{H}-2$ and signals at $\delta_{\mathrm{C}} 197.3(\mathrm{C}-4), 131.6\left(\mathrm{C}-1^{\prime}\right), 114.8$ (C$\left.2^{\prime}\right)$, and $119.2\left(\mathrm{C}-6^{\prime}\right)$, indicating the connectivity between the $\mathrm{B}$ - and $\mathrm{C}$ - rings at $\mathrm{C}-2$. The comparison of NMR data of $\mathbf{2}$ and those of eriodictyol showed that they were identical, thus $\mathbf{2}$ was elucidated as eriodictyol [19]. Eriodictyol was isolated in E. acanthothamnos [20] and many plants but this is the first time found in Euphorbia tirucalli. This compound possessed antiinflamatory effect [21].

Compound 3 was obtained as a light-yellow amorphous powder. Analysis of 1D NMR data of $\mathbf{3}$ indicated that $\mathbf{3}$ was a flavonoid glycoside with the presence of L-rhamnopyranosyl moiety, comprising an amomeric proton signal at $\delta_{\mathrm{H}} 5.19$ $(1 \mathrm{H}, \mathrm{d}, J=1.5 \mathrm{~Hz}, \mathrm{H}-1 ")$, four oxygenated proton signals in the ${ }^{1} \mathrm{H}$ zone of $3.1-4.0 \mathrm{ppm}$, and a characteristic methyl signal at $\delta_{\mathrm{H}} 0.91(3 \mathrm{H}, \mathrm{d}, J=$ $6.0 \mathrm{~Hz}, \mathrm{H}-6 ")$. The NMR data of the aglycone moiety of $\mathbf{3}$ were similar with those of $\mathbf{2}$ (Table 2), except for the absence of the methine $\mathrm{CH}-2$ and the methylene $\mathrm{CH}_{2}-3$ groups in $\mathbf{2}$ and the presence of a new double bond between C-2 and C-3. This finding was confirmed by the HMBC correlation of H-2' and H-6' and C-2 ( $\left.\delta_{\mathrm{C}} 158.4\right)$ (Fig. 3). The rhamnose moiety was linked to the aglycone moiety at its C-3, which was proved by the HMBC correlation of porom ignal at $\delta_{\mathrm{H}} 5.52(\mathrm{H}-$ 1") and carbon C-3 135.9). All mentioned spectroscopic data vel matched with those of quercitrin re literature [22]. Quercitrin was already pouted from this species [10].

Compand 4 was obtained as a light-yellow amorphois powder. The comparison of 1D NMR data of 4 and 3 (both recorded in acetone- $d_{6}$ ) and thed that 4 was also a flavonoid glycoside wi h the presence of L-rhamnopyranosyl moiety, except for the absence of the hydroxy group in Bring of the aglycone moiety (Table 2). This finding was confirmed by the presence of the 1,4disubstituted benzene moiety in $\mathbf{4}$ instead of the $1,2,4$ trisubtitued benzene in B-ring in 3 . The HMBC correlations between $\mathrm{H}-2^{\prime} / 6^{\prime}$ and $\mathrm{C}-2\left(\delta_{\mathrm{C}}\right.$ 158.4), C-3' $\left(\delta_{\mathrm{C}}\right.$ 116.1), and C-4' $\left(\delta_{\mathrm{C}} 161.0\right)$ supported this finding (Fig. 3). The comparison of NMR data of $\mathbf{4}$ and those of afzelin showed that they were identical, thus $\mathbf{4}$ was elucidated as afzelin [23]. Afzelin had been isolated in other Euphorbia plants such as E. hirta but this is the first time isolated in Euphorbia tirucalli [24].

Compound 5 was obtained as a light-yellow amorphous powder. Its ${ }^{1} \mathrm{H}$ NMR spectrum revealed the presence of seven resonances comprising two cis olefinic protons at $\delta_{\mathrm{H}} 7.84$ $(1 \mathrm{H}, \mathrm{d}, J=9.5 \mathrm{~Hz}, \mathrm{H}-4)$ and $6.17(1 \mathrm{H}, \mathrm{d}, J=9.5$ $\mathrm{Hz}, \mathrm{H}-3)$, two singlet aromatic protons $\delta_{\mathrm{H}} 6.80$ $(\mathrm{H}-8)$ and $7.19(\mathrm{H}-5)$, one methoxy group at $\delta_{\mathrm{H}}$ $3.90(3 \mathrm{H}, \mathrm{s})$. The ${ }^{13} \mathrm{C}$ NMR of $\mathbf{5}$ showed ten carbon signals including one carbonyl ester group at $\delta_{\mathrm{C}} 160.4(\mathrm{C}-2)$, four methine moieties at $\delta_{\mathrm{C}}$ 143.7 (C-4), 112.4 (C-3), 109.1 (C-5), and 102.8 (C-8), one methoxy group at $\delta_{\mathrm{C}} 55.7$, and four aromatic quaternary carbons at $\delta_{\mathrm{C}} 111.2(\mathrm{C}-10)$, 
144.9 (C-6), 150.9 (C-9), and 154.1 (C-7) (three latter oxygenated). These NMR data of $\mathbf{5}$ were similar to those of scopoletin, accordingly, $\mathbf{5}$ was elucidated as scopoletin [25]. The HMBC correlations of $\mathbf{5}$ supported its structure as described in Fig. 2. Scopoletin was found in $E$. hirta or E. heteradena [26] but this is isolated from Euphorbia tirucalli for the first time.

Table 2. NMR spectral data of compounds 2-4

\begin{tabular}{|c|c|c|c|c|c|c|c|c|c|}
\hline \multirow{2}{*}{ Position } & \multicolumn{3}{|c|}{2} & \multicolumn{3}{|c|}{3} & \multicolumn{3}{|c|}{4} \\
\hline & $\delta_{\mathrm{C}}$ & $\delta_{\mathrm{H}}, \mathrm{m}$ & $J(\mathrm{~Hz})$ & $\delta_{\mathrm{C}}$ & $\delta_{\mathrm{H}}, \mathrm{m}$ & $J(\mathrm{~Hz})$ & $\delta_{\mathrm{C}}$ & $\delta_{\mathrm{H}}, \mathrm{m}$ & $J(\mathrm{~Hz})$ \\
\hline 2 & 80.0 & 5.40 & $\mathrm{dd}, 12.5,3.0$ & 158.4 & & & 158.4 & & \\
\hline 3 & 43.6 & $\begin{array}{l}3.14 \\
2.72 \\
\end{array}$ & $\begin{array}{l}\mathrm{dd}, 17.0,12.5 \\
\mathrm{dd}, 17.0,12.5 \\
\end{array}$ & 135.9 & & & 135.6 & & \\
\hline 4 & 197.3 & & & 179.4 & & & nd & & \\
\hline 5 & 165.3 & & & 163.2 & & & 163.2 & & \\
\hline 6 & 96.8 & 5.94 & $\mathrm{~d}, 2.0$ & 99.3 & 6.26 & $\mathrm{~d}, 2.0$ & 98.8 & 6.26 & $\mathrm{~d}, 2.0$ \\
\hline 7 & 167.4 & & & 164.9 & & & 164.9 & & \\
\hline 8 & 95.9 & 5.96 & $\mathrm{~d}, 2.0$ & 94.7 & 6.46 & $\mathrm{~d}, 2.0$ & 93.5 & 6.46 & $\mathrm{~d}, 2.0$ \\
\hline 9 & 164.4 & & & 158.0 & & & 1.7 .5 & & \\
\hline 10 & 103.2 & & & 105.7 & & & $10 . \overline{5}$ & & \\
\hline$\overline{1}^{\prime}$ & 131.6 & & & 122.9 & & & $1) \longdiv { 1 . 0 }$ & & \\
\hline $2 '$ & 114.8 & 7.03 & $\mathrm{~d}, 1.5$ & 116.1 & 7.51 & $\mathrm{~d}, 2 . \mathrm{C}$ & 728.5 & 7.86 & $\mathrm{~d}, 8.5$ \\
\hline $3^{\prime}$ & 146.1 & & & 149.0 & & & 116.1 & 7.01 & $\mathrm{~d}, 8.5$ \\
\hline $4^{\prime}$ & 146.5 & & & 145.8 & & & 161.0 & & \\
\hline $5^{\prime}$ & 116.1 & 6.86 & $\mathrm{~d}, 8.5$ & 116.8 & 6.98 & & 116.8 & 7.01 & $\mathrm{~d}, 8.5$ \\
\hline $6^{\prime}$ & 119.2 & 6.87 & $\mathrm{dd}, 8.5,1.5$ & 122.6 & 7.40 & d, s. $5,2.0$ & 128.5 & 7.86 & $\mathrm{~d}, 8.5$ \\
\hline $1 "$ & & & & 102.8 & 5.521 & br & 102.8 & 5.54 & $\mathrm{~d}, 1.5$ \\
\hline $2 "$ & & & & 71.3 & 4.22 & $\mathrm{~m}$ & 71.2 & 4.21 & $\mathrm{dd}, 3.0,1.5$ \\
\hline $3 "$ & & & & 71.5 & & $\mathrm{dd}, 9.0,3.0$ & 71.4 & 3.74 & $\mathrm{dd}, 8.5,3.0$ \\
\hline $4 "$ & & & & 73.0 & -4 & $\mathrm{~m}$ & 73.2 & 3.33 & $\mathrm{~m}$ \\
\hline $5 "$ & & & & 726 & 3.33 & $\mathrm{~m}$ & 72.2 & 3.30 & $\mathrm{~m}$ \\
\hline $6 "$ & & & & 17 & 0.91 & $\mathrm{~d}, 6.0$ & 17.9 & 0.90 & $\mathrm{~d}, 5.5$ \\
\hline $5-\mathrm{OH}$ & & 12.17 & $\mathrm{~s}$ & & 12.72 & $\mathrm{~s}$ & & 12.71 & $\mathrm{~S}$ \\
\hline
\end{tabular}

nd: not determined
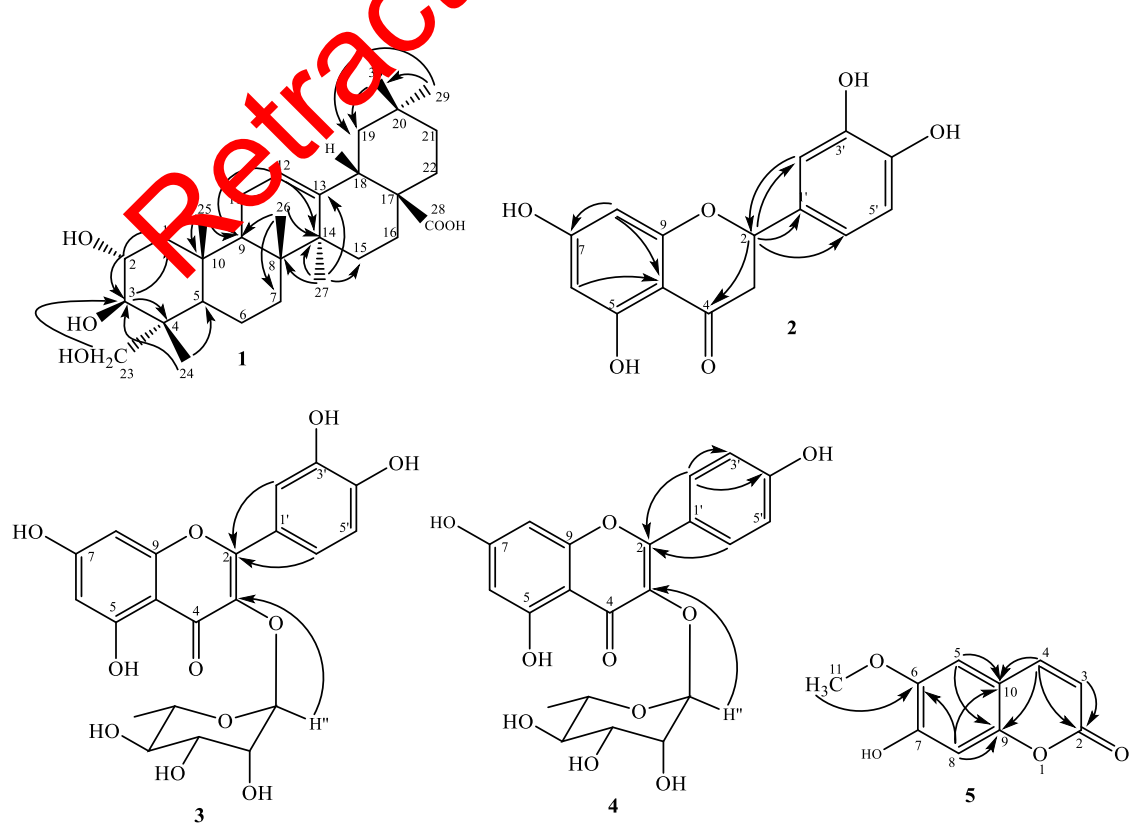

Н нмвС

Fig. 2. Selected HMBC correlations of $\mathbf{1 , 2 , 3 , 4}$ and $\mathbf{5}$ 


\section{CONCLUSION}

From Euphorbia tirucalli collected in Binh Thuan province, seven compounds were isolated and elucidated, including arjunolic acid (1), eriodictyol (2), quercitrin (3), afzelin (4), scopoletin (5), 3,3',4-trimethylellagic acid (6), and gallic acid (7). Among them, compound $\mathbf{1}$ was found for the first time in Euphorbia genus while three compounds $\mathbf{2}, \mathbf{4}$, and 5 were firstly isolated from this species. Furthermore, compounds $\mathbf{1}$ and 6 were confirmed as major components of this species.

\section{REFERENCES}

[1] N. Sharma, K.W. Samarakoon, R. Gyawali, Y.H. Park, S.J. Lee, S.J. Oh, T.H. Lee, D.K. Jeong, "Evaluation of the antioxidant, anti-inflammatory, and anticancer activities of Euphorbia hirta ethanolic extract", Molecules, vol. 19, pp. 14567-14581, 2014.

[2] J. Mwine, P.V. Damme, B.R. Hastilestari, J. Papenbrock, "Euphorbia tirucalli L. (Euphorbiaceae), the miracle tree: current status of knowledge", ACS Symposium Series, 1127 (African Natural Plant Products Volume II), pp. 3-17, 2013.

[3] K.M. de Araujo, A. de Lima, J.doN. Silva, L.L. Rodrigues et al., "Identification of phenolic compoun. and evaluation of antioxidant and antimicro ial properties of Euphorbia tirucalli L., Antioxidan $\$$ 3, no. 1, pp. 159-175, 2014.

[4] C.K. Ramesh, M.N. Prabha, S.A. Peepan K.N Madhusudhan, "Screening of antiviral pre nery against tobamoviruses in latex of Euphorbig (ir 10 lli L", Indian Journal of BioTechnology, vol.3, 1, 1, . . 1-3, 2009.

[5] S.S. Santana, M.L. Gennari Ca dos, F.C. Carvalho, M.C. Roque-Barreira, S.Sar iPe Ada, F.C. Alvim, C.P. Pirovani, "Eutirucall $n, \mathrm{R} .2 \mathrm{~L}$ type lectin from the latex of Euphorbia tin alli L. presents proinflammatory properties", Plos One, vo 9, no. 2, e88422, 2014.

[6] J.M.M. Dias, C.P. Chaves, "Combination of active fractions from the plants Euphorbia tirucalli L. and Ficus carica L. and method of treating cancer and AIDS", PCT Int. Appl, WO 2006007676 A1 20060126, 2006.

[7] B.A. Avelar, F.J.N. Lelis, R.S. Avelar, M. Weber, E.M. Souza Fagundes, M.T.P. Lopes, O.A. Martins Filho, G.E.A. Brito-Melo, "The crude latex of Euphorbia tirucalli modulates the cytokine response of leukocytes, especially CD4+T lymphocytes", Revista Brasileira de Farmacognosia, vol. 21, no. 4, pp. 662-667, 2011.

[8] H. Uchida, H. Yamashita, M. Kajikawa, K. Ohyama, O. N. Osamu, R. Sugiyama, K. T. Yamato, T. Muranaka, H. Fukuzawa, M. Takemura, K. Ohyama, "Cloning and characterization of a squalene synthase gene from a petroleum plant, Euphorbia tirucalli L.”, Planta, vol. 229, no. 6, pp. 1243-1252, 2009.

[9] A. Chatterjee, M. Chakrabarty, A.K. Ghosh, "Trimethylellagic acid from Euphorbia tirucalli L.", Indian J. Chem. B., vol. 15, pp. 564-565, 1977.
[10] S.J. Lin, C.H. Yeh, L.M. Yang, P.C. Liu, F.L. Hsu, "Phenolic Compounds from Formosan Euphorbia tirucalli", Journal of the Chinese Chemical Society, vol. 48, no. 1, pp. 105-108, 2001.

[11] T. Yoshida, K. Yokoyama, O. Namba, T. Okuda, "Tannins and related polyphenols of euphorbiaceous plants: VII. Tirucallins A, B and euphorbin F, monomeric and dimeric ellagitannins from Euphorbia tirucalli L.", Chemical and Pharmaceutical Bulletin, vol. 39, pp. 1137-1143, 1991.

[12] G. Fuerstenberger, E. Hecker, "New highly irritant euphorbia factors from latex of Euphorbia tirucalli L.", Experientia, vol. 33, no. 8, pp. 986-988, 1977.

[13] G. Fuerstenberger, E. Hecker, "On the active principles of the spurge family (Euphorbiaceae). XI. [1] The skin irritant and tumor promoting diterpene esters of Euphorbia tirucalli L. originating from South Africa, Zeitschrift fuer Naturforschung, C: Journal of Biosciences, vol. 40C, no. pp. 631-646, 1985.

[14] M. Watanabe, Y. Kob vasni, J. Ogihara, J. Kato, K. Oishi, "HIV-1 $\mathrm{A}$ vorse transcriptase-inhibitory compound in 0 officinalis", Food Science and Technolog Ra earoh, vol. 6, no. 3, p. 218, 2000.

[15] S.B. Makatto A.P. Kundu, " ${ }^{13} \mathrm{C}-\mathrm{NMR}$ spectra of pentac lic sterpenoids-a compilation and some salient fea ar , hytochemistry, vol. 37, no. 6, pp. 271727281194

[16] Kalola, M. Rajani, "Extraction and TLC desitometric etermination of triterpenoid acids (Arjungenin, a) unolic acid) from Terminalia arjuna stem bark without interference of tannins", Chromatographia, vol. 63, 475e $481,2006$.

[17] J. Ghosh, P.C. Sil, "Review Arjunolic acid: A new multifunctional therapeutic promise of alternative medicine", Biochimie, vol. 95, 1098e1109, 2013.

[18] N.M. Elsherbiny, M.M.H. Al-Gayyar, "Anti-tumor activity of arjunolic acid against Ehrlich ascites carcinoma cells in vivo and in vitro through blocking TGF- $\beta$ type 1 receptor", Biomedicine \& Pharmacotherapy, vol. 82, pp. 28-34, 2016. 
[19] Y.H. Huang, W.M. Zeng, G.Y. Li, G.Q. Liu, D.D. Zhao, J. Wang, Y.L. Zhang, "Characterization of a new sesquiterpene and antifungal activities of chemical constituents from Dryopteris fragrans (L.) Schott", Molecules, vol. 19, no. 1, pp. 507-513, 2014.

[20] V. Myrianthopoulos, N. Fokialakis, P. Magiatis, N Aligiannis, B. Tekwani, A.L. Skaltsounis, "Constituents of Euphorbia acanthothamnos and evaluation of their antileishmanial activity", Planta Med., vol. 74, PB164, 2008.

[21] J.K. Lee, "Anti-inflammatory effects of eriodictyol in lipopolysaccharidestimulated raw 264.7 murine macrophages", Archives of Pharmacal Research, vol. 34, no. 4, pp. 671-679, 2011.

[22] S. Bose, S. Maji, P. Chakraborty, "Quercitrin from Ixora coccinea leaves and its anti-oxidant activity", Journal of
Pharma. Sci. Tech., vol. 2, no. 2, pp. 72-74, 2013.

[23] Z. Zhang, H.N. ElSohly, X.C. Li, S.I. Khan, S.E. Broedel, R.E. Raulli, R.L. Cihlar, C. Burandt, L.A. Walker, "Phenolic compounds from Nymphaea odorata, J. Nat. Prod., vol. 66, no. 4, pp. 548-550, 2003.

[24] Y. Liu, N. Murakami, H. Ji, P. Abreu, S. Zhang, "Antimalarial flavonol glycosides from Euphorbia hirta", Pharmaceutical Biology, vol. 45, no. 4, pp. 278281, 2007.

[25] W. Liu, J. Hua, J. Zhou, H. Zhang, H. Zhu, Y. Cheng, R. Gust, "Synthesis and in vitro antitumor activity of novel scopoletin derivatives", Bioorganic \& Medicinal Chemistry Letters, vol. 22, pp. 5008-5012, 2012.

[26] S. Okuzs, A. Ulubelen, A. Barla, "Terpenoids and aromatic compounds from Euphorbia heteradena", Turk J. Chem., vol. 26, pp. 457-463, 2002.

\title{
Thành phần hóa học của cây ẩ giao (Euphorbia tirucan.)
}

Lê Thị Kim Dung ${ }^{1}$, Bùi Xuân Hào ${ }^{1}$, Nguyễn Thị Ánb-Ttuêt ${ }^{1}$, Phạm Nguyễn Kim Tuyến ${ }^{2}$, Dương Thúc Huy

\author{
${ }^{1}$ Trường Đại học Sư phạm Tłòn phố Hồ Chí Minh \\ ${ }^{2}$ Trường $\mathrm{n}$ nọ Să gòn \\ Tác giả liênhệ̣: hu, dt $\mathrm{c}$ hcmue.edu.vn
}

Ngày nhận bản thảo 29-05-2017; ngày châ Jnhận đăng 12-10-2018; ngày đăng 20-11-2018

Tóm tắt- Cây Cành giao Euphorbiñ trucalli chưa được nghiên cứu nhiều ở Việt $\mathrm{Nm}$. Nghiên cứu này mô tả sự phân lập và xác đị̂lûu trúc hóa học của một số hợp chất từ cẩ Canh giao sinh trưởng ở Bình Thuận. Các phườopháp sắc ký cột silica gel pha thuận và sŏ́n $k$ ở mỏng đã được sử dụng. Bảy hợp chất ươ cộ̂ và cấu trúc của chúng được xác định b.ng các phương pháp phổ nghiệm cũng như so sánh với tài liệu tham khảo. Chúng là arjunolic acid (1), eriodictyol (2), quercitrin (3), afzelin (4), scopoletin (5), 3,3',4trimethylellagic acid (6), và gallic acid (7) được cô lập. Trong số chúng, arjunolic acid được biết là thành phần chính trong cây thuộc chi Euphorbia. Các hợp chất 2, 4, 5 lần đầu tiên được cô lập từ loài Euphorbia tirucalli.

Tù̀ khóa-arjunolic acid, các họ̣p chất phenolic, flavonoid, Euphorbia tirucalli 